Diabetologia 3, 453-459 (1967)

\title{
Radioimmunoassay of Insulin in Urine
}

\author{
A.H. Rubenstein*, C. Lowy and T. Russell Fraser
}

Departments of Medicine, Royal Postgraduate Medical School, London W. 12. and the University of the Witwatersrand, Johannesburg, South Africa

Received March 8, 1967

Sumary. 1. Details are given of a double antibody immunoassay method suitable for measuring insulin in urine. -2 . The method proved specific and reproducible. Human insulin added to urine was quantitatively recovered and dilution and concentration resulted in proportional changes in measured insulin. -3 . Urines kept at $4^{\circ} \mathrm{C}$ for 24 hours showed no loss of assayable insulin, while decreases of $4-23 \%$ were observed after standing at room temperature for 24 hours; samples of urine adjusted to $\mathrm{pH} 7.4-8.4$ and centrifuged were kept at $-20^{\circ} \mathrm{C}$ for 9 months without loss. Addition of albumin to urine to prevent adsorption of insulin on the container was found to be unnecessary. - 4. Tests of the first antibody reaction showed that non-specific co-precipitation of radioactive insulin was less than $3.5 \%$ and that addition of sodium chloride did not alter the standard insulin curve. Monitor tubes containing ${ }^{131} \mathrm{I}$-guinea-pig gammaglobulin showed optimal second antibody precipitation in all the urine assays surveyed. - 5 . In normal subjects, the renal clearance of insulin was relatively constant over a wide range of serum insulin levels, but varied with body size. However, preliminary studies suggested that the clearance was reduced in pregnancy, hypertension and peripheral vaseular disease, all of which are characterized by high serum insulin values. In contrast, the clearance in acromegaly was normal as both serum and urine insulin levels were raised. In chronic renal disease the urinary excretion of insulin was very high. - 6. Direct measurement of urinary insulin was feasible in insulintreated diabeties provided that renal function was normal; insulin-binding antibodies were found in the urine of these diabetics only in association with proteinuria.

Dosage radio-immunologique de l'insuline dans l'urine.

Résumé. 1. Des détails sont donnés sur la méthode de dosage immunologique avec double anticorps pour mesurer l'insuline dans l'urine. - 2. Il a été prouvé que la méthode est spécifique et reproductible. De l'insuline humaine ajoutée à de I'urine a été retrouvée quantitativement et les différentes dilutions et concentrations ont donné les résultats escomptés. - 3. Des urines qui ont été gardées pendant 24 heures à $4^{\circ} \mathrm{C}$, n'ont pas perdu d'insuline, tandis qu'on a observé une perte de 4 à $23 \%$ après que l'urine ait été laissée pendant 24 heures à la température de la pièce. De l'urine dont le $\mathrm{pH}$ a été ajusté entre 7.4 et 8.4 , centrifugée et mise à $-20^{\circ} \mathrm{C}$ n'a pas montré de perte pendant 9 mois. On a trouvé, que l'addition d'albumine à l'urine pour prévenir l'adsorption de l'insuline sur le tube n'est pas nécessaire. - 4. L'étude de la réaction du premier anticorps a démontré que la co-précipitation non spécifique de l'insuline radio-active était inférieure à $3.5 \%$, et que l'addition de sodium et de chlorure ne change pas la courbe standard de l'insuline. Des tubes témoins contenant de la ${ }^{131}$ I-gamma-globuline de cobaye ont montré une précipitation optimale du deuxième anticorps dans toutes les expériences faites avoc

* Based on a paper presented to the 6th Congress of the International Diabetes Federation, Stockholm 1967, while in receipt of S.L. Sive Memorial Travelling Fellowship. de l'urine. - 5. Chez des sujets normaux la clearance rénale de l'insuline était relativement constante sur une grande échelle de taux d'insuline sérique, mais elle variait avec le poids du corps. Cependant des études préliminaires ont montré que pendant la grossesse, dans l'hypertension et les maladies vasculaires périphériques, toutes caractérisées par des taux élevés d'insuline sérique, la clearance est diminuée. Par contre dans l'acromégalie la clearance est normale, alors que les taux de l'insuline sérique et urinaire étaient élevés. Dans les maladies rénales chroniques l'excrétion urinaire de l'insuline était très forte. - 6. La détermination directe de l'insuline urinaire était réalisable chez des diabétiques traités à l'insuline, à condition que la fonction rénale soit normale; on a trouvé des anticorps anti-insuline dans les urines de ces diabétiques seulement lorsqu'il existe une protéinurie. Harn.

Die radioimmunologische Bestimmung von Insulin im

Zusammenfassung. 1. In der vorliegenden Arbeit wird eine Methode zum Insulinnachweis im Urin mit einer Doppel-Antikörpermethode im einzelnen angegeben. 2. Die Methode ist spezifisch und reproduzierbar. Menschliches Insulin, das dem Uxin beigegeben wurde, wird quantitativ wieder gefunden. Verdünnung und Konzentrierung bewirken proportionale Änderungen des gemessenen Insulins. - 3. Urin, der über 24 Stunden bei $4^{\circ} \mathrm{C}$ gehalten wurde, zeigte keinen Verlust an untersuchbarem Insulin; während nach Stehen in Raumtemperatur für 24 Stunden eine Abnahme von 4-23\% beobachtet wurde. Urinproben mit eingestelltem $\mathrm{pH}$ von $7.4-8.4$, zentrifugiert und bei $-20^{\circ} \mathrm{C}$ gehalten, zeigten bis zu 9 Monaten keinen Verlust. Zusatz von Albumin in den Urin, um die Adsorption von Insulin an der Glaswand zu verhüten, ist für unnötig befunden worden. -4 . Versuche der ersten Antikörper-Reaktion zeigten, daß die unspezifische Mit-Präzipitation von radioaktivem Insulin kleiner als $3.5 \%$ war und daß die Zugabe von Natrium und Chlorid die Insulin-Standardkurve nicht verändern. KontrollReagenzgläser mit ${ }^{131}$ I-Meerschweinchen Gammaglobulin. zeigten einen optimalen zweiten Antikörper Niederschlag in allen Urinversuchen. - 5. Die Nieren-Clearance von Insulin war bei normalen Personen über eine weite Reihe von Serum-Insulin-Werten relativ konstant, aber variierte mit der Körpergröße. Jedoch haben vorausgehende Studien darauf hingedeutet, daß die Clearance reduziert ist während der Schwangerschaft, bei hohem Blutdruck und peripheren vasculären Krankheiten, welche alle charakterisiert sind durch hohe Insulinwerte. Dafür war die Clearance bei Akromegalie normal, denn beide, Serum- und Urin-Insulinwerte waren erhöht. Bei chronischen Nierenkrankheiten war die Insulinausscheidung im Urin sehr hoch. - 6. Direkte Messung von Urin-Insulin war bei Diabetikern ausführbar die mit Insulin behandelt wurden, vorausgesehen, daß die Nierenfunktion normal war; insulin-bindende Antikörper wurden nur im Urin von Diabetikern mit Proteinurie gefunden.

Key-words: Urine insulin, Radioimmunoassay, Method, Measurement, Clearance, Kidney, Control Subjects, Insulin-treated diabeties, Acromegaly, Renal failure. 
Immunoassay techniques for the measurement of many protein hormones are now well established, and recognised to be both specific and sensitive [1]. Almost every method has been directed towards measurement of these hormones in blood, and a great deal of information has been obtained regarding the factors regulating their plasma concentrations [2]. However, a few reports have described the presence of protein hormones in urine [6,7], a finding which is in accord with the demonstration of trace amounts of other proteins in normal urine [10]. The clearance of proteins into urine is inversely proportional to their molecular weight [4] and is governed mainly by glomerular permeability, although tubular reabsorption of filtered protein does occur [4].

We have previously reported insulin levels in the urine of normal subjects [11], and in this paper we describe the application of the double antibody immunoassay procedure to measurement of urine insulin, and some factors influeneing its renal excretion.

\section{Material and Methods}

The double antibody immunoassay of insulin used was that of WrLborN and Fraser [16] modified from MORGaN and LAZARow [8]. Twice recrystallized human insulin of potency 23.25 i.u./mg determined chromatographically by the method of FenToN [3] (and kindly donated by the M.R.C. and Wellcome Laboratories) was used for standards and in recovery experiments.

Table 1. Procedure for the preparation and assay of urine insulin by the double antibody immunoassay method

Preliminary Preparation

Keep at $4^{\circ} \mathrm{C}$.

Adjust $\mathrm{pH}$ to $7.4-8.4$ with concentrated ammonium hydroxide.

Centrifuge at $4^{\circ} \mathrm{C}$ for $15 \mathrm{~min}$. at 2000 r.p.m.

Decant supernatant and discard precipitate.

First Antibody Reaction

$1.0 \mathrm{ml}$ prepared urine sample (or standard insulin)

$0.1 \mathrm{ml}$ 125I-insulin

$0.1 \mathrm{ml}$ guinea-pig anti-insulin serum (diluted)

Incubate at $4^{\circ} \mathrm{C}$ for 6 days.

Second Antibody Reaction

$0.1 \mathrm{ml}$ guinea-pig serum (diluted) + 25 i. u. heparin

$0.1 \mathrm{ml}$ rabbit anti-guinea-pig gamma-globulin serum (diIuted)

Incubate at $4^{\circ} \mathrm{C}$ for 24 hours.

Centrifuge at $4^{\circ} \mathrm{C}$ for 30 min. at 2000 r.p.m.

Decant supernatant.

Count precipitate and supernatant.

Radioactive insulin, labelled with either ${ }^{131} \mathrm{I}$ or ${ }^{125} \mathrm{I}$ was obtained from the Radiochemical Centre, Amersham and the guinea-pig anti-insulin serum (GPAI serum) from the Wellcome Laboratories. The assay involves a 6-day incubation of the first antibody system with a subsequent 24 hour precipitation of the insulin antibody complex by a rabbit anti-serum prepared against pure guinea-pig gamma-globulin (RAGP $\gamma$ ). The standard procedure for measuring urine insulin is outlined in Table 1.

Insulin-binding antibodies in serum and urine were demonstrated using the ethanol precipitation procedure of WELBORN et al. [15].

\section{Results}

A. Applicability of the double antibody immunoassay to urine

\section{Dilution}

The method used allows for the assay of sample volumes up to $1.0 \mathrm{ml}$. Many urine specimens were measured over the range $0.1-1.0 \mathrm{ml}$ and two representative experiments are shown in Fig. 1. The dilutions lie along a curve parallel to that of human insulin standards. Further, samples were often estimated at two dilutions in the same assay with good agreement between the two readings (Table 2 ).

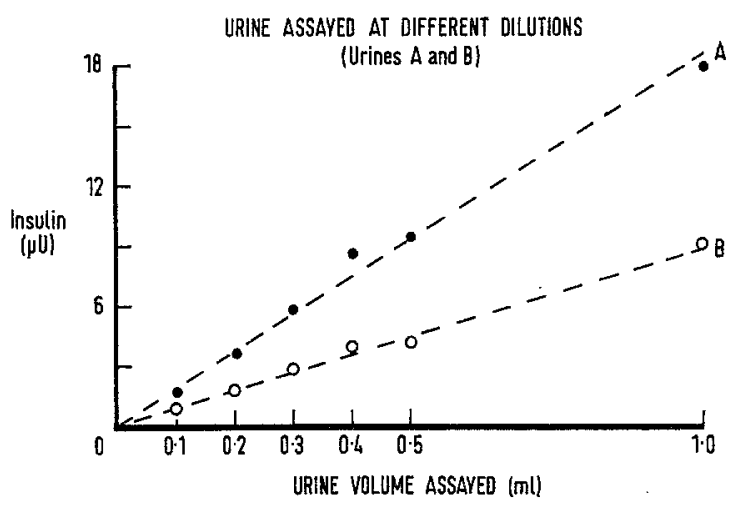

Fig. 1. Assay of two specimens of urine (A and B) in dilutions ranging from 1 in 10 to undiluted (i.e. $1.0 \mathrm{ml}$ ). The dilutions fall along straight lines

\section{Recoveries}

Human insulin added to urine was fully recovered over a wide range of concentrations (Fig. 2). There was no evidence of rapid degradation of insulin, endogenous or exogenous, in voided urine kept at $4^{\circ} \mathrm{C}$ for up to 24 hours (Fig. 2).

\section{3. $p H$ Effect}

As preliminary tests revealed variable recovery and dilution effects with urines at low $\mathrm{pH}$, aliquots of a sample of acid urine were adjusted to $\mathrm{pH}$ 's between 6.6 and 8.8 with concentrated ammonium hydroxide and subsequently assayed. The results indicate that the percentage insulin bound to antibody was constant between $\mathrm{pH} 7.4$ and 8.4 (Fig. 3). Furthermore, the recovery of exogenous human insulin added to urine was complete when the assay was carried out in this $\mathrm{pH}$ range. 


\section{Salt concentration}

The reactivity of insulin antibodies is influenced by the concentration of various ions, notably chloride, iodide and nitrate [5], and this may be particularly important where relatively large volumes of sample are assayed at the expense of the diluting buffer. The diluent in the assay is a borate buffer, which has a chloride concentration of $36 \mathrm{mFq} / \mathrm{L}$. In order to check the salt sensitivity of the antibody used in our laboratory, urine specimens with very low salt concentrations (obtained from a patient who had been fasting for 10 days) were assayed in $1.0 \mathrm{ml}$ volumes before and after the addition of quantities of sodium chloride equivalent to that in $1.0 \mathrm{ml}$ of buffer. There were no differences in the final insulin results. In a further experiment, 38 and $77 \mathrm{mEq} / \mathrm{L}$ of sodium chloride were added to the buffer without affecting the standard curve (Table 3).

Table 2. Assay of urine samples at different dilutions. The values for non-specific co-precipitation of ${ }^{125} I$-insulin (in control tubes set up without GPAI-serum) and for completeness of the second antibody reaction (in monitor tubes set up with ${ }^{131}$ I-guinea-pig gamma-globulin $\left({ }^{131} I\right.$-GPY)) are included

\begin{tabular}{|c|c|c|c|c|}
\hline $\begin{array}{l}\text { Urine } \\
\text { Sample }\end{array}$ & $\begin{array}{l}\text { Volume } \\
\text { Assayed } \\
\text { (ml) }\end{array}$ & $\begin{array}{l}\text { Non-specific } \\
\text { 195I-insulin } \\
\text { co-precipitation } \\
\text { (\% precipitated) }\end{array}$ & $\begin{array}{l}{ }^{131} \mathbf{I}-\mathrm{GP} \gamma \\
\text { precipitation } \\
\text { (\% of optimal } \\
\text { buffer value) }\end{array}$ & $\begin{array}{l}\text { Insulin } \\
(\mu \mathrm{U} / \mathrm{ml})\end{array}$ \\
\hline 1 & $\begin{array}{l}0.5 \\
1.0\end{array}$ & $\begin{array}{l}2.2 \\
3.3\end{array}$ & $\begin{array}{l}101 \\
103\end{array}$ & $\begin{array}{l}1.6 \\
1.5\end{array}$ \\
\hline 2 & $\begin{array}{l}0.5 \\
1.0\end{array}$ & $\begin{array}{l}1.7 \\
2.4\end{array}$ & $\begin{array}{r}99 \\
103\end{array}$ & $\begin{array}{l}1.8 \\
1.9\end{array}$ \\
\hline 3 & $\begin{array}{l}0.5 \\
1.0\end{array}$ & $\begin{array}{l}2.5 \\
2.5\end{array}$ & $\begin{array}{l}98 \\
99\end{array}$ & $\begin{array}{l}3.0 \\
3.2\end{array}$ \\
\hline 4 & $\begin{array}{l}0.5 \\
1.0\end{array}$ & $\begin{array}{l}3.1 \\
2.9\end{array}$ & $\begin{array}{r}97 \\
103\end{array}$ & $\begin{array}{l}3.8 \\
3.6\end{array}$ \\
\hline 5 & $\begin{array}{l}0.5 \\
1.0\end{array}$ & $\begin{array}{l}2.4 \\
2.7\end{array}$ & $\begin{array}{l}100 \\
100\end{array}$ & $\begin{array}{l}20.0 \\
18.8\end{array}$ \\
\hline 6 & $\begin{array}{l}0.5 \\
1.0\end{array}$ & $\begin{array}{l}3.0 \\
2.8\end{array}$ & $\begin{array}{r}97 \\
100\end{array}$ & $\begin{array}{l}32.0 \\
34.6\end{array}$ \\
\hline 7 & $\begin{array}{l}0.1 \\
0.5 \\
1.0\end{array}$ & $\begin{array}{l}2.2 \\
3.0 \\
2.6\end{array}$ & $\begin{array}{l}101 \\
100 \\
101\end{array}$ & $\begin{array}{l}18.0 \\
17.2 \\
18.4\end{array}$ \\
\hline
\end{tabular}

insulin, but otherwise prepared as the standard assay tubes, have also revealed optimal precipitation of the

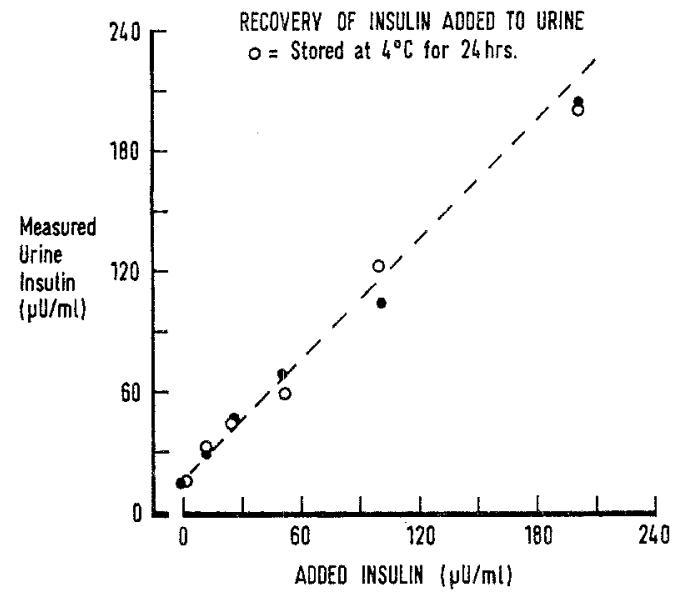

Fig. 2. Recovery of human insulin $(10-200 \mu \mathrm{U} / \mathrm{ml})$ added to urine and assayed immediately, $(\bullet)$ and after standing at $4^{\circ} \mathrm{C}$ for 24 hours (o).

\section{EFFECT OF URINE PH DN INSULIN ASSAY}

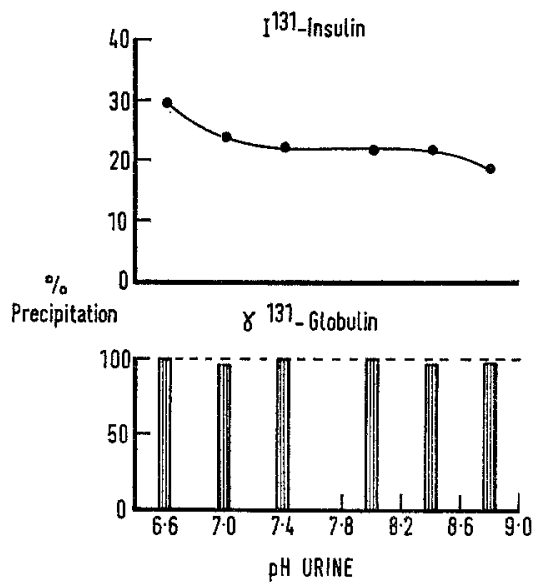

Fig. 3. Effect of $\mathrm{pH}$ on first and second antibody reactions. The percentage ${ }^{131}$ I-insulin precipitated was constant between $\mathrm{pH} 7.4$ and 8.4, while the precipitation of ${ }^{131}$ I-gamma-globulin (measured in monitor tubes as an index of second antibody precipitation) was complete at all $\mathrm{pH}$ values

Table 3. Failure of Sodium Chloride to Infuence the Standard Insulin Curve

\begin{tabular}{lllllll}
\hline \multirow{2}{*}{ (Insulin, $\mu \mathrm{U} / \mathrm{ml})$} & \multicolumn{7}{l}{ Percentage ${ }^{126} \mathrm{I}$-insulin precipitated } & & \\
\cline { 2 - 7 } & $(0)$ & $(1.25)$ & $(2.5)$ & $(5.0)$ & $(10.0)$ & $(20.0)$ \\
\hline Borate Buffer & 70.2 & 61.6 & 54.9 & 42.6 & 31.2 & $\mathbf{2 1 . 1}$ \\
Borate Buffer + NaCl $(38 \mathrm{mEq} / \mathrm{L})$ & 71.2 & 62.6 & 54.9 & 41.8 & 31.2 & 19.6 \\
Borate Buffer + NaCl $(77 \mathrm{mEq} / \mathrm{L})$ & $\mathbf{6 9 . 4}$ & $\mathbf{6 1 . 1}$ & $\mathbf{5 3 . 6}$ & 42.5 & 30.1 & 20.9
\end{tabular}

\section{Consistency of the second antibody reaction}

The above tests checking the validity and reproducibility of the assay have implied consistent performance of both the first and second antibody reactions when applied to urine. Monitor tubes containing ${ }^{131} \mathrm{I}$-guinea-pig gamma-globulin (GP $\gamma$ ) instead of ${ }^{131} \mathrm{I}$ - second antibody in over 100 urine specimens, including samples concentrated 8-fold (Table 2). The standard procedure includes the addition of heparin (25 i.u. being added to each tube with the second antibody reagents), without which incomplete precipitation has sometimes been observed. The usefulness of the ad- 
dition of heparin has already been reported with serum [16]. Complete precipitation was observed over the range of $\mathrm{pH}$ and salt concentration required for the first antibody reaction (Fig. 3).

6. Non-specific co-precipitation of labelled insulin.

Non-specific precipitation of radioactive insulin by RAGP $\gamma$ serum in urine samples set up without insulin antibodies was never greater than $3.5 \%$ (Table 2) even in specimens concentrated 40 -fold.

\%. Collection, storage and preparation of urine for assay

a) Addition of albumin. To test whether this was necessary, urine was collected in plain glass bottles and after the removal of control aliquots, crystalline bovine albumin (Fraction 5 of Armour Pharmaceutical Co.) was added to a concentration of $1 \%$. The levels of insulin assayed were similar before and after the addition of albumin. (Fig. 4). In further experiments albumin was added to containers prior to the collection of urine, but again no difference was observed between these results and those of aliquots of the same urines passed directly into bottles containing no albumin.

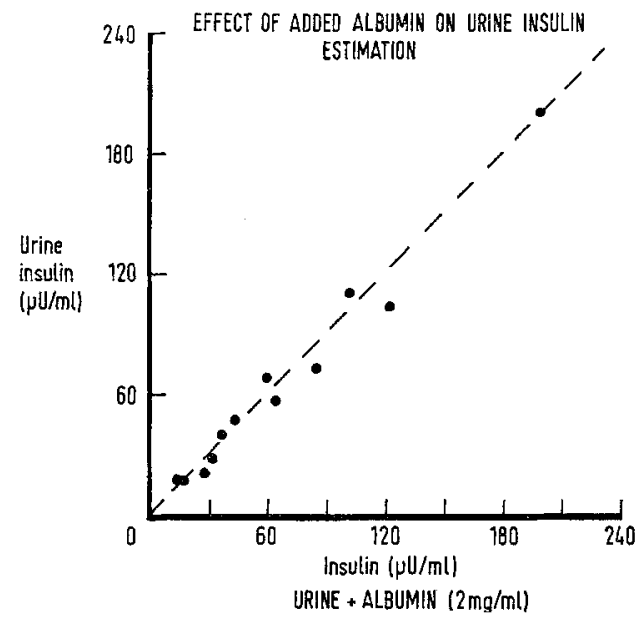

Fig. 4. Assay of urine samples before and after the addition of crystalline bovine albumin (Fraction V) c) Concentration of urine. Although the majority of urines contain sufficient insulin to be directly measured by this assay technique, samples too dilute for the method are occasionally encountered. A number of methods for concentrating urine have been evaluated. Benzoic acid precipitation resulted in losses of up to $80 \%$, while precipitation by ethanol or RAGP $\gamma$ serum after the addition of excess insulin antibody (and subsequent acid-ethanol extraction) is prohibitively expensive. Large volumes of urine $(300-500$ $\mathrm{ml}$ ) may be conveniently concentrated in a rotary vacuum evaporator with insulin recoveries of up to $70-90 \%$. Smaller volumes can be handled in Visking tubing of porosity $18 / 32$ utilizing carbowax as the hygroscopic agent. Recoveries with this latter procedure ranged between $60-90 \%$ (Table 5), which is similar to results obtained after dialysing urine without concentration [6].

B. Significance of the rate of urinary excretion of insulin

1. Renal clearance in normal subjects at various serum insulin levels

Four volunteers were given $50 \mathrm{~g}$ of glucose per hour orally and blood and urine samples were collected

Table 5. Immunoassay of Insulin in Urine before and after Concentration in Visking tubing (18/32). Carbowax was used outside the tubing as the hygroscopic agent

\begin{tabular}{|c|c|c|c|c|}
\hline \multirow{2}{*}{ Sample } & \multirow{2}{*}{$\begin{array}{l}\text { Volume after } \\
\text { concentration } \\
\text { (ml) }\end{array}$} & \multicolumn{2}{|c|}{$\begin{array}{l}\text { Insulin Assayed } \\
\text { (total } \mu \mathrm{U} / \text { sample) }\end{array}$} & \multirow{2}{*}{$\begin{array}{l}\text { Percentage } \\
\text { Recovery }\end{array}$} \\
\hline & & $\begin{array}{l}\text { Before con- } \\
\text { centration }\end{array}$ & $\begin{array}{l}\text { After con- } \\
\text { centration }\end{array}$ & \\
\hline $\begin{array}{l}\text { A } 1 \\
(100 \mathrm{ml})\end{array}$ & - & 1520 & - & - \\
\hline $\begin{array}{l}2 \\
3 \\
4\end{array}$ & $\begin{array}{l}56 \\
41 \\
22\end{array}$ & & $\begin{array}{r}1076 \\
1130 \\
968\end{array}$ & $\begin{array}{l}71 \% \\
74 \% \\
64 \%\end{array}$ \\
\hline $\begin{array}{l}\mathrm{B} 1 \\
(80 \mathrm{ml})\end{array}$ & - & 1016 & - & - \\
\hline $\begin{array}{l}2 \\
3 \\
4\end{array}$ & $\begin{array}{l}34 \\
27 \\
13\end{array}$ & & $\begin{array}{l}856 \\
972 \\
754\end{array}$ & $\begin{array}{l}84 \% \\
96 \% \\
74 \%\end{array}$ \\
\hline
\end{tabular}

Table 4. Effects of Storage of Urine on its Assayable Insulin

\begin{tabular}{llll}
\hline Storage Conditions & $\begin{array}{l}\text { No. of } \\
\text { samples }\end{array}$ & $\begin{array}{l}\text { Initial insulin } \\
\text { concentration }(\mu \mathrm{U} / \mathrm{ml}) \\
\text { (mean and range) }\end{array}$ & $\begin{array}{l}\text { Percent change } \\
\text { in stored samples } \\
\text { (mean and range) }\end{array}$ \\
\hline $\begin{array}{l}24 \text { hours at room } \\
\text { temperature }\end{array}$ & 4 & $11.7(1.4-18.0)$ & $-12.4(3.9$ to -23.3$)$ \\
$\begin{array}{l}3-9 \text { months storage } \\
\text { in deep freeze }\end{array}$ & 9 & $15.7(4.3-53.0)$ & $+4.0(-20$ to +25.6$)$
\end{tabular}

b) Stability of urine insulin. No decrease in insulin recoveries was observed in samples stored at $4^{\circ} \mathrm{C}$ for 24 hours. Standing at room temperature for 24 hours resulted in losses of up to $25 \%$ in immunoassayable insulin (Table 4). Urines were stored at $-20^{\circ} \mathrm{C}$ in plain bottles for 9 months with no decrease in measurable insulin (Table 4). over a number of hours. There was an initial fall in the insulin clearance as the serum level rapidly rose, followed by a return of the clearance to basal levels. The range of insulin clearance in these subjects was $0.15-0.5 \mathrm{ml} / \mathrm{min}$, and remained relatively constant despite an increase in the serum insulin concentration of 3-to 20-fold (Fig. 5). 


\section{The effect of body size}

The preceding experiments show that, in any one individual, varying serum levels of insulin are reflected in corresponding changes in urinary excretion of the hormone. Elsewhere [11] we have shown that the urinary excretion of insulin in normal subjects also varies with body size, probably because renal clearance is influenced by this parameter. Therefore serum insulin concentration should correlate best with the urinary excretion of insulin corrected for body size, for which purpose urinary insulin/mg creatinine or per $\mathrm{hr} / \mathrm{kg}$ body weight were better corrections than urinary albumin or body surface area [11]. In normal subjects during a 2-hour glucose tolerance test, the insulin clearance ranged from $0.23-0.87 \mathrm{ml} / \mathrm{min}$ with a mean value of $0.42 \mathrm{ml} / \mathrm{min}$ [11]. In these same normal subjects the mean ratio of the insulin clearance to the creatinine clearance was $3.90 \times 10^{-3}$ (range $1.64 \times$ $10^{-3}$ to $7.17 \times 10^{-3}$ ) and the mean insulin clearance/ $70 \mathrm{~kg}$ body weight was $0.48 \mathrm{ml} / \mathrm{min}$ (range 0.27 to $0.87)$.

\section{INSULIN CLEARANCE AT VARYING SERUM LEVELS}

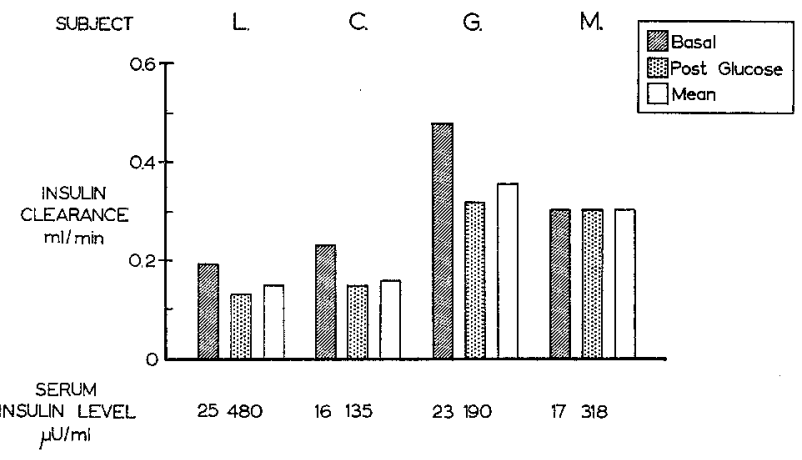

Fig. 5. Insulin clearances in four healthy volunteers under basal conditions and following oral glucose administration. The mean clearance value for each subject is derived from 6 to 10 clearance periods of $30-40$ minutes duration

3. Some conditions where the renal clearance of insulin is abnormal

Clearly renal disease is likely to be associated with abnormal insulin clearance, and some assessment of renal function must always be made when urinary insulin is being studied. In patients suffering from chronic renal disease, with a severe reduction in creatinine clearance, the urine insulin excretion and the insulin clearance were markedly raised. To assess whether the insulin clearance would be normal in conditions associated with high serum insulin levels, studies were carried out in 8 acromegalies. In this group both the serum and urine insulin were raised and the elearances were normal (Fig. 6).

However, in some other conditions with raised serum insulin levels, unexpected abnormalities of insulin clearance were encountered (Fig. 6). As reported elsewhere [13], the fourfold rise in serum insulin levels during the third trimester of pregnancy is accom- panied by urine insulin values within the normal range. The insulin clearances were thus lower than in the normal group, although the simultaneously measured creatinine clearances showed the expected rise. The pattern in patients with hypertension and peripheral vascular disease was essentially similar to that found in pregnancy, although the creatinine clearance was usually normal or slightly reduced. Further studies are in progress to clarify these abnormalities.
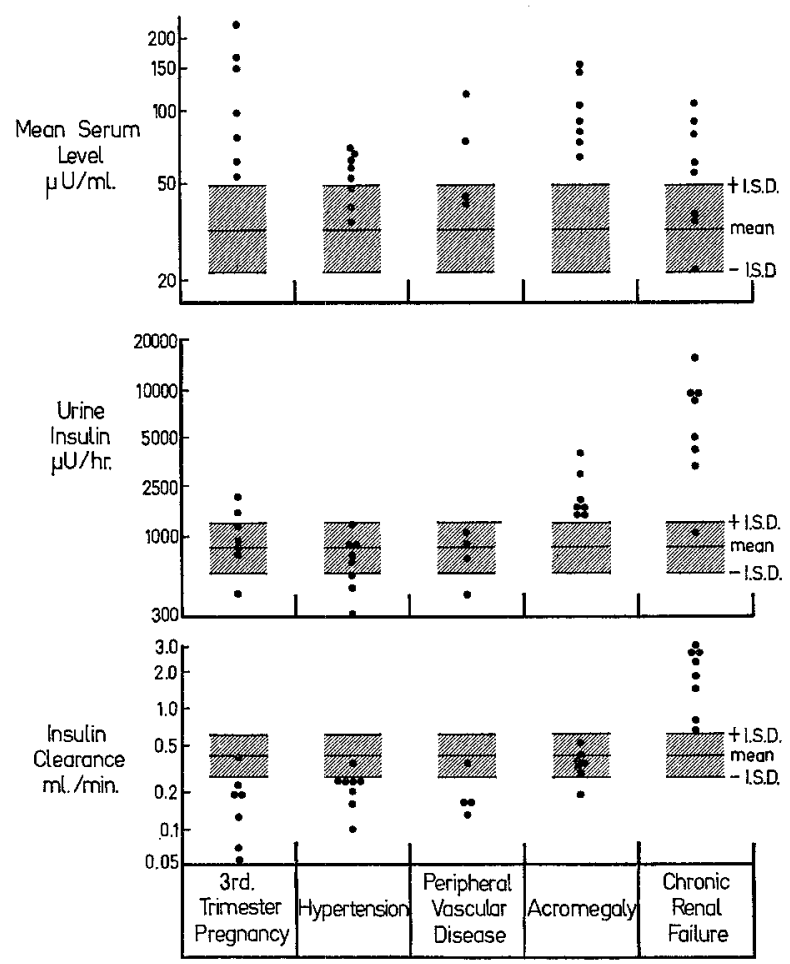

Fig. 6. Serum and urine insulin values and insulin clearances in various conditions. The mean and 1 S.D. in normal subjects [11] is shown. The vertical axis has a logarithmic scale

\section{Urinary insulin in insulin-treated diabetics}

The measurement of insulin in the urine of diabetic subjects receiving exogenous insulin may prove to be a valuable reflection of non-antibody-bound (and therefore active) hormone in these subjects. The normal glomerulus is relatively impermeable to the large gamma-globulin insulin antibodies, and thus predominantly unbound insulin would be filtered. As plasma levels of insulin are not easily measurable by immunoassay in these patients [1], urine insulin would provide a useful alternative. Antibody binding of ${ }^{125}$ I-insulin in serum and urine was measured by ethanol precipitation in 20 insulin-requiring diabetics. Blood and urine samples were collected after an overnight fast and before the injection of the morning dose of insulin. Urine protein was estimated using albustix ${ }^{1}$.

\footnotetext{
${ }^{1}$ Ames Company, Stokes Poges, Slough, Bucks., England.
} 
The results indicate a good correlation between proteinuria and the presence of insulin binding antibodies in the urine (Fig. 7), and thus it should be feasible to measure urine insulin in insulin-treated diabeties who do not show proteinuria.

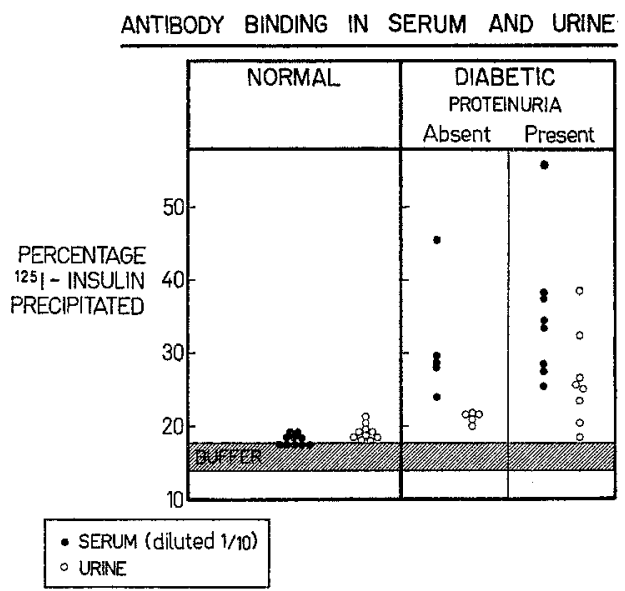

Fig. 7. Binding of ${ }^{125} \mathrm{I}$-insulin in serum and urine of control and diabetic subjects as determined by ethanol precipitation

\section{Discussion}

Various modifications of the double antibody immunoassay procedure have been used for estimation of serum insulin. The predominant problem has been impaired precipitation of the insulin antibody complex during the second-antibody reaction, with resultant spuriously high values [16]. This has been circumvented by prolonged incubation [12] and by the addition of E.D.T.A. [9] or heparin [16] and the results are now comparable to those obtained by chromato-electrophoresis. Application of these principles and safeguards has enabled us to obtain a reproducible, specific and sensitive method for measurement of urinary insulin. Dilutional curves and recoveries of added insulin indicate that the substance measured behaves similarly to standards of crystalline human insulin and immunologically reactive serum insulin. It needs emphasis that while the experiments reported here have established that this double antibody immunoassay of insulin can be used for urine, it may not follow that other types of immunoassay are also applicable to urine without hazard of artefacts. Indeed, since urine is much more variable in osmolarity and electrolyte content than serum, it may be that the single antibody procedure in which the free and unbound insulin are separated by chromato-electrophoresis will prove to be more unreliable than the double antibody procedure in these circumstances.

Because of the known sensitivity of some insulin antibodies to different chloride concentrations [5], it is important to use an antibody which is fully reactive at the relatively low ion concentrations that may be encountered in dilute urines. Alternatively, sodium chloride should be added to all specimens to ensure an optimal concentration. In the initial experiments, impairment of second-antibody precipitation was observed in concentrated and acid specimens of urine, but this has been overcome by our recommended $\mathrm{pH}$ adjustment and centrifugation.

Insulin in urine is stable when stored at $4^{\circ} \mathrm{C}$ for periods of up to 24 hours and this facilitates the use of the assay for routinely collected samples. Although JøRGENSEN [6] has added bovine albumin to the container in which urine was collected in order to prevent loss of insulin onto the glass, our experiments indicate that this is unnecessary. The addition of albumin to the bottle did not result in higher measured values of insulin, and there was complete recovery of human insulin added to urine samples standing in glass containers for $\mathbf{2 4}$ hours. It seems most likely that urinary insulin is protected by the small amount of albumin and mucoproteins present. All samples are now stored at $4^{\circ} \mathrm{C}$ for up to 24 hours until processed. The $\mathrm{pH}$ is then adjusted to 7.4-8.4 and the sample is centrifuged; the decanted supernatent can then be deep frozen at $-20^{\circ} \mathrm{C}$.

Although the majority of urine samples can be measured directly with the range of volumes available for this assay, occasional specimens are too dilute. Of a number of methods for concentrating urine which have been evaluated, none is entirely satisfactory. Concentration through Visking tubing or under vacuum in a rotary evaporator resulted in recoveries of $70-90 \%$, but the other methods tried proved inferior.

The independence of renal clearance from the serum concentration of insulin in normal subjects fortunately gives a good prospect for assessing insulin secretory function from urinary insulin studies. The urinary excretion rate should be corrected for body size in order to give the closest reflection of the serum insulin, and we have found that expressing the insulin value in terms of kilograms of body weight or milligrams of creatinine is satisfactory.

As noted elsewhere [11], the insulin clearances derived during a standard 2 hour $50 \mathrm{~g}$ oral glucose tolerance test (GTT) in 28 normal subjects are within the same range as those obtained under basal conditions; thus the mean insulin excretion rate during the 2 hours of the GTT is a useful index of a subject's secretory response to glucose.

Clearly the interpretation of urinary insulin values must always be made in the light of an appraisal of the subject's renal elearance of insulin. Indeed our studies suggest that the interpretation of serum insulin values should be similarly cautious unless renal function is known to be normal. The mechanisms underlying the abnormal insulin clearances in pregnancy, ehronic renal failure, hypertension and peripheral vascular disease are not clear, and must await more detailed 
knowledge of insulin excretion by the normal kidney. Although alteration in renal function may account for the findings, it is also possible that serum insulin may be protein-bound or polymerized to differing degrees in some of the above conditions. This would result in a fall of filtered insulin and low clearances. It is interesting that low clearances occur in several conditions characterized by high serum insulin levels, and increased incidence of impaired glucose tolerance and "insulin resistance" $[13,14]$. If only a part of the measured serum insulin, in equilibrium with a bound fraction, was available for glomerular filtration and passage out of the vascular compartment, it would provide an explanation for the normal glucose tolerance and absence of hypoglycaemia in these subjects.

The immunoassay of urinary insulin seems likely to be practicable in insulin-treated diabetics, a group of patients in whom serum insulin has not proved easily measurable hitherto. Unmodified immunoassay methods cannot be used for the direct measurement of insulin in the blood of patients who have previously been treated with insulin for longer than a few weeks [1]. Insulin-binding antibodies in their blood compete with the assay's antibody for the labelled insulin, and as the human antibody is not precipitated by the RAGP $\gamma$-serum, spuriously high values for serum insulin result. JøRGENSEN [6] measured urinary insulin in diabetic patients receiving parental insulin and found that the daily excretion of insulin was similar to normal subjects. However his patients were being treated with insulin for the first time when the measurements were carried out, and would not be expected to have insulin-binding antibodies in their blood. It was therefore important to establish whether diabetics with serum insulin-binding antibodies excreted insulin in their urine, and whether the gamma-globulin antibody was present in urine in concentrations which would invalidate the assay. The results using ethanol precipitation showed no increase in binding of labelled insulin in urine obtained from diabeties with normal renal function. As might be anticipated, insulin antibodies were present in urine containing protein and there was a rough correlation between the degree of proteinuria and insulin binding. The feasibility of measuring insulin in the urine of insulin-requiring diabetics opens up possibilites of studying diabetic control, estimating effective insulin reaching the extravascular compartment, noting the time course of release of injected long-acting insulins and determining those factors and events which may influence antibody-binding of insulin, such as infections and steroids.

Acknowledgements. Part of this study was performed during a Smith and Nephew Scholarship (A.H.R.). The project was supported in South Africa by a grant from the South African Sugar Industries for diabetic research.
- We wish to thank Drs T.A. WeuborN, A.D. Wright and I.M. TRAYNER for valuable advice and help and Miss S. LEUTARDT for technical assistance.

\section{References}

[1] Berson, S.A., and R.S. YaLow: Immunoassay of protein hormones. In The Hormones, edited by G. Pincus, K.V. Thimann and E.B. Astwood. New York and London, Academic Press, vol IV, $p$. $557-630$ (1964).

[2] Ciba Foundation Colloquia on Endocrinology. Immunoassay of Hormones, edited by G.E.W. WoLSTENHOLME and M.P. CAMERON. London, J. and A. Churchill, vol. 14 (1962).

[3] Fenton, E.L.: A method for the assay of insulin by paper chromatography. Biochem. J. 71, 507-513 (1959).

[4] HaRdwicke, J., and J.R. SQUIRE: The relationship between plasma albumin concentration and protein excretion in patients with proteinuria. Clin. Sci. 14, $509-530(1955)$.

[5a] Heding, L. : Ethanol precipitation as a substitute for the double antibody reaction in a simplified insulin immunoassay method. First Annual Meeting of European Association for the Study of Diabetes, Montecatini Terme, 1965.

[5b] Hedrng, L.: Personal Communication.

[6] JøRGENSEN, K.R. : Immunoassay of insulin in human urine. Acta endocr. (Kbh) 51, 400-410 (1966).

[7] McARThUR, R.G., and L. STIMLIER: Urinary insulin excretion in healthy children and in siblings of childhood onset diabetics. Lancet 1966 I, 1236-1237.

[8] Morgar, C.R., and A. Lazarow: Immunoassay of insulin: two antibody system. Diabetes 12, 115-126 (1963).

[9] - R.L. Sorenson and A. Lazarow: Studies of an inhibitor of the two antibody immunoassay system. Diabetes 13, $1-5(1964)$.

[10] Rrgas, D.A., and C.G. HerLer: The amount and nature of urinary proteins in normal human subjects. J. clin. Invest. 30, 853-861 (1951).

[11] Rubenstein, A.H., C. Lowy, T.A. Welborn and $T$. RUsseur Fraser: Urine insulin in normal subjects. Metabolism 16, 234-244 (1967).

[12] Soeldenter, J.S., and D. Stone: Critical variables in the radio-immuno-assay of serum insulin using the double antibody technic. Diabetes 14, 771-779 (1965).

[13] Trayner, I.M., T.A. Welborn, A.H. Rubenstein and T. Russell Fraser: Serum and urine insulin in late pregnancy and in a few pregnant latent diabetics. J. Endocr. 37, 443-453 (1967).

[14] Werborn, T.A., A. Breckenridge, A.H. Ruberstein, C.T. Dollery and T. Russelt Fraser: Serum insulin in essential hypertension and in peripheral vascular disease. Lancet $1966 \mathrm{I}, 1336-1337$.

[15] - R. Richards and T. Russell Fraser: A simple test for insulin antibodies in sera, using ${ }^{131} \mathrm{I}$-insulin and ethanol precipitation. Brit. Med. T. 1, 719-722 (1967).

[16] - , and T. Russela Fraser: The double-antibody immunoassay of insulin. Diabetologia 1, 211-218 (1965).

T. Russell Fraser, M.D.

Royal Postgraduate Medical School

Department of Medicine

Ducane Road

London, W. 12, England 